\title{
Late Mandibular Angle Fracture After Impacted Third Molar Extraction - Case Report and Review of Predisposing Factors
}

\author{
Fractura Tardía de Ángulo de Mandibula Post Extracción de Tercer Molar Impactado \\ - Reporte de un Caso y Revisión de Factores Predisponentes
}

Valdir Cabral Andrade; Patrício José de Oliveira Neto; Márcio de Moraes \& Luciana Asprino

ANDRADE, V. C.; NETO, P. J. O.; DE MORAES, M. \& ASPRINO, L. Late mandibular angle fracture after impacted third molar extraction - case report and review of predisposing factors. Int. J. Odontostomat., 7(2):287-292, 2013.

ABSTRACT: Third molar surgery is the most common surgical procedure in the oral cavity. Whenever extraction is indicated, careful planning based on clinical and radiographic examinations is essential to guard against postoperative complications like: bleeding, alveolitis, infections, injury to adjacent teeth, oroantral communications, or even mandibular fractures. Although rare, the risk of postoperative mandibular fractures after third molar impaction surgery is related to some factors. Our case report a 50-year-old white female patient with a complaint of pain in the region of the left mandibular angle and stated that three weeks before she had the left mandibular third molar extracted, which computerized tomographic confirmed the presence of a fracture in the mandibular angle. However, our report contributes to showing the predisposing factors to cause this injury after a review of the literature, showing the clinician what they should take like consideration when they indicate the extraction of third molars. To avoid this complication, factors like bony impaction, depth of tooth within bone, proximity to the inferior dental canal, tooth position in relation to adjacent teeth, the presence of root dilacerations and others must be taken into account. A case of late mandibular fracture that occurred 21 days after third molar extraction is reported. Conservative treatment was adopted and after six-months of radiographic and clinical follow-up, the patient had fully preserved mandibular function, normal occlusion and no discomfort.

KEY WORDS: third molar, extraction, Mandibular fracture, late complication.

\section{INTRODUCTION}

The surgical removal of impacted third molars is a procedure frequently performed by oral and maxillofacial surgeons. Third molar removal needs to be carefully planned with strict reference to the clinical and radiographic examinations because of associated risks of complications such as bleeding, damage to the inferior alveolar nerve, alveolitis, secondary infections and even mandibular fractures. Mandibular fracture during third molar removal or afterwards is a rare event with an incidence of $0.0049 \%$, as reported by Libersa, et al. (2002) and Perry \& Goldberg (2000). Several aspects need to be analyzed in the preoperative period to ensure that the removal of such teeth has been correctly indicated and is carried out using the appropriate surgical technique (Custódio et al., 2007; Ellis \& Sinn, 1993) among which are depth of impaction, tooth angulation, and the patient's age. Furthermore, the mandibular angle is an area of low resistance with a compact upper border but thin basilar bone (Assael, 1994), and the removal of the impacted third molar makes it even more fragile (Kruger, 1982; Krimmel \& Reinert, 2000). This clinical report describes a case of late mandibular fracture following third molar extraction.

\section{CASE REPORT}

A 50-year-old white female patient, was referred to our department with a complaint of pain in the region of the left mandibular angle. During anamnesis the 
patient stated that three weeks before she had the left mandibular third molar extracted. When she was chewing a piece of bread, she heard a click and immediately began to feel pain in the region. Physical examination revealed a soft swelling, painful on palpation, in the left mandibular angle region. Mandibular movements were all normal and there were no observable changes in the patient's dental occlusion. The alveolar mucosa of left mandibular third molar was healing and there was a slight purulent secretion. There was no mobility in the surrounding region in response on palpation. Records of the patient case showed that surgery had been difficult and lasted longer than planned; extensive osteotomy was performed and heavy bleeding had been controlled using bone wax. The preoperative panoramic radiograph showed that the lower left third molar was mesioangular (Pell and Gregory Class II, position B) and very close to the mandibular canal (Figure 1). A postoperative panoramic radiograph was taken and it revealed signs of a fracture involving the angle of the left mandible (Figs. 1 and 2). Computerized tomographic imaging was used to obtain a better visualization of the affected region and confirmed the presence of a fracture in the mandibular angle but with no apparent displacement of the

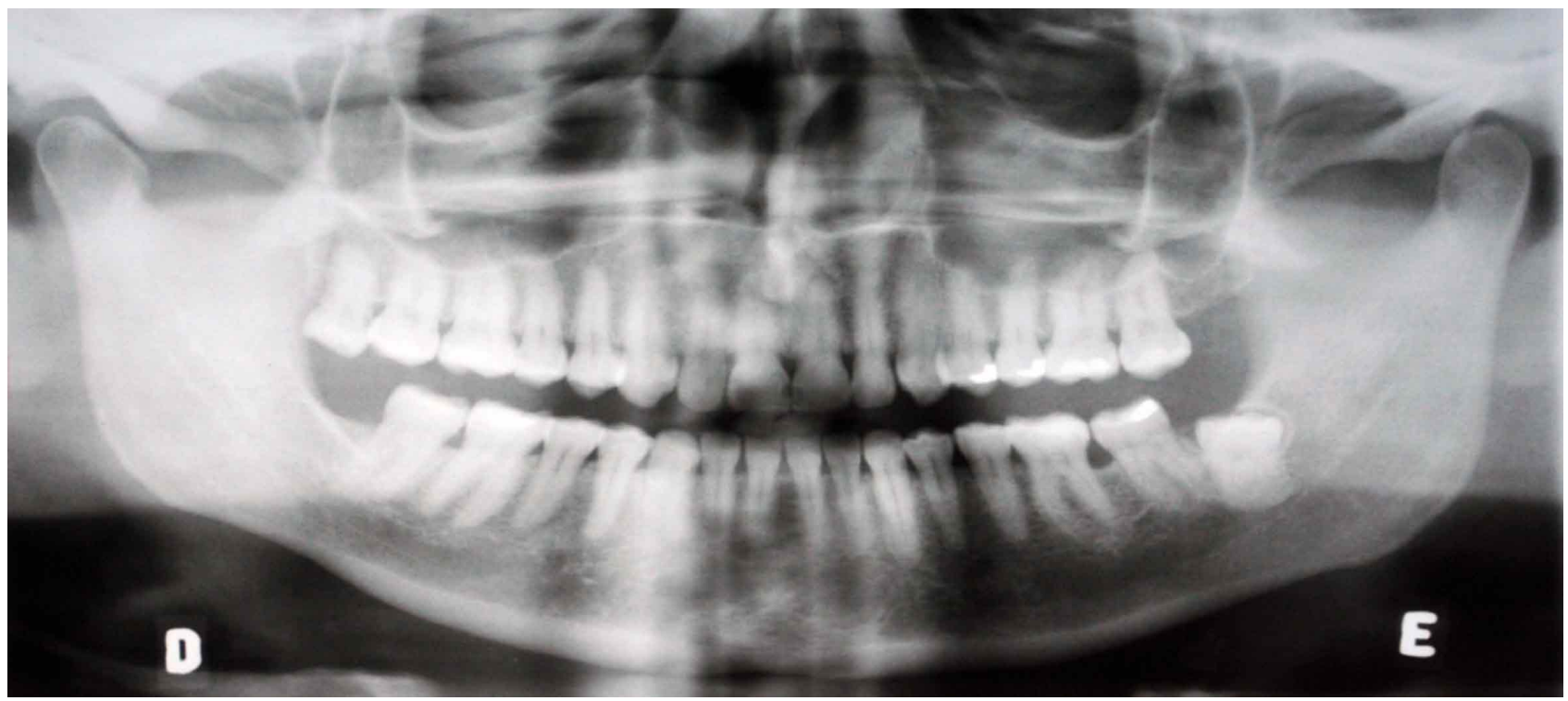

Fig. 1. Preoperative panoramic radiograph.

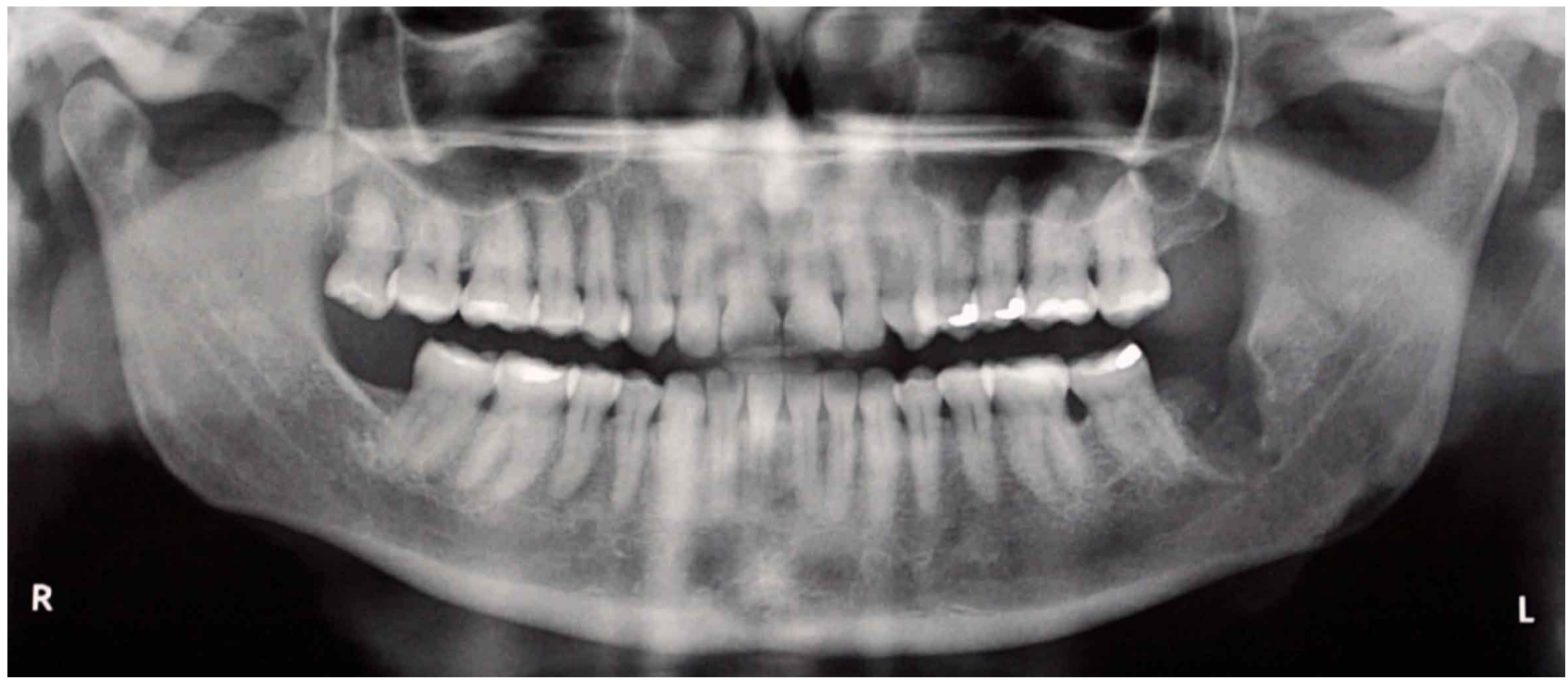

Fig. 2. Postoperative panoramic radiograph. 
fragments (Fig. 3). In view of these clinical and radiographic signals, it was decided to opt for a conservative treatment of the fracture, avoiding any surgical intervention Accordingly, the patient was advised to make a soft and liquid diet for 45 days. The patient was advised that surgery would be considered only if alterations to the patient's occlusion, abnormal mandibular movement or mobility and displacement of the fracture fragments were detected.
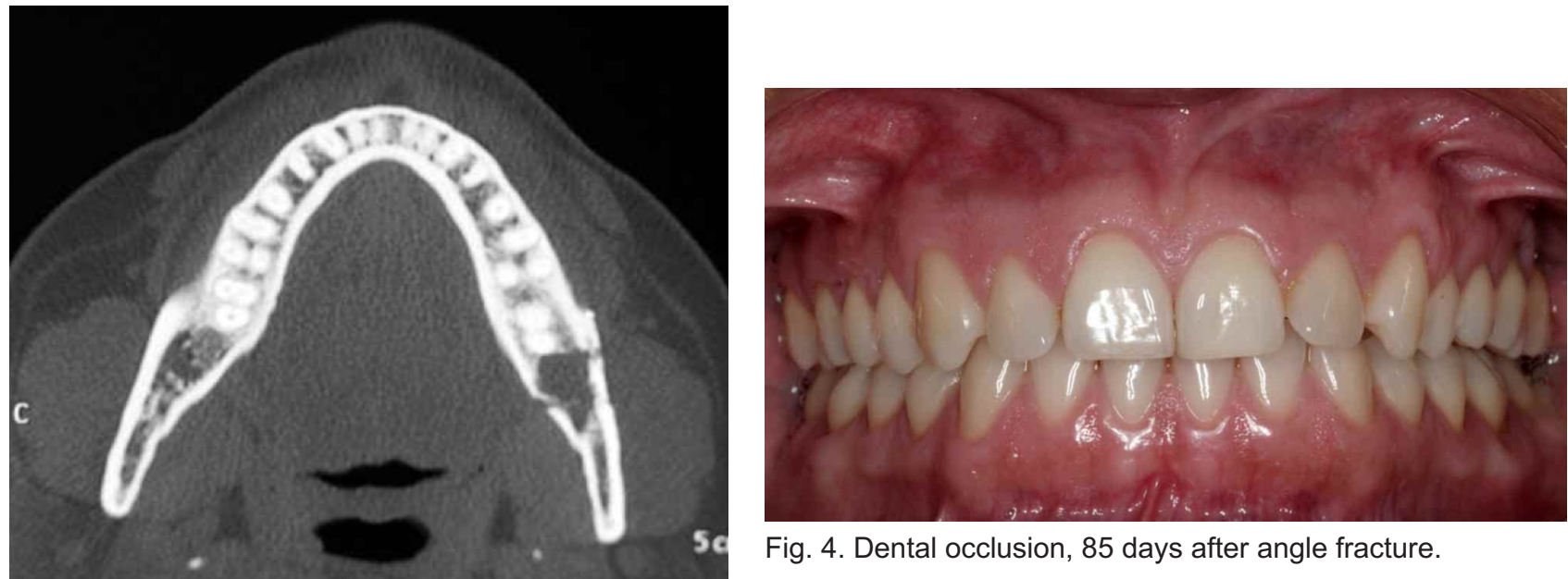

Fig. 3. CT scan, 30 days after third molar extraction.
Weekly follow up was maintained for the first month to check for signs of infection or occlusion alterations. After 2 months the patient's mandibular movements and occlusion were perfectly preserved, she no longer felt any pain and the swelling in the region of the left mandibular angle had gone down. Clinical and radiological follow up after 6 months (Figs. 4 and 5 ) showed that the patient's dental occlusion and mandibular function were perfectly preserved and the patient herself had no discomfort.
Fig. 4. Dental occlusion, 85 days after angle fracture.

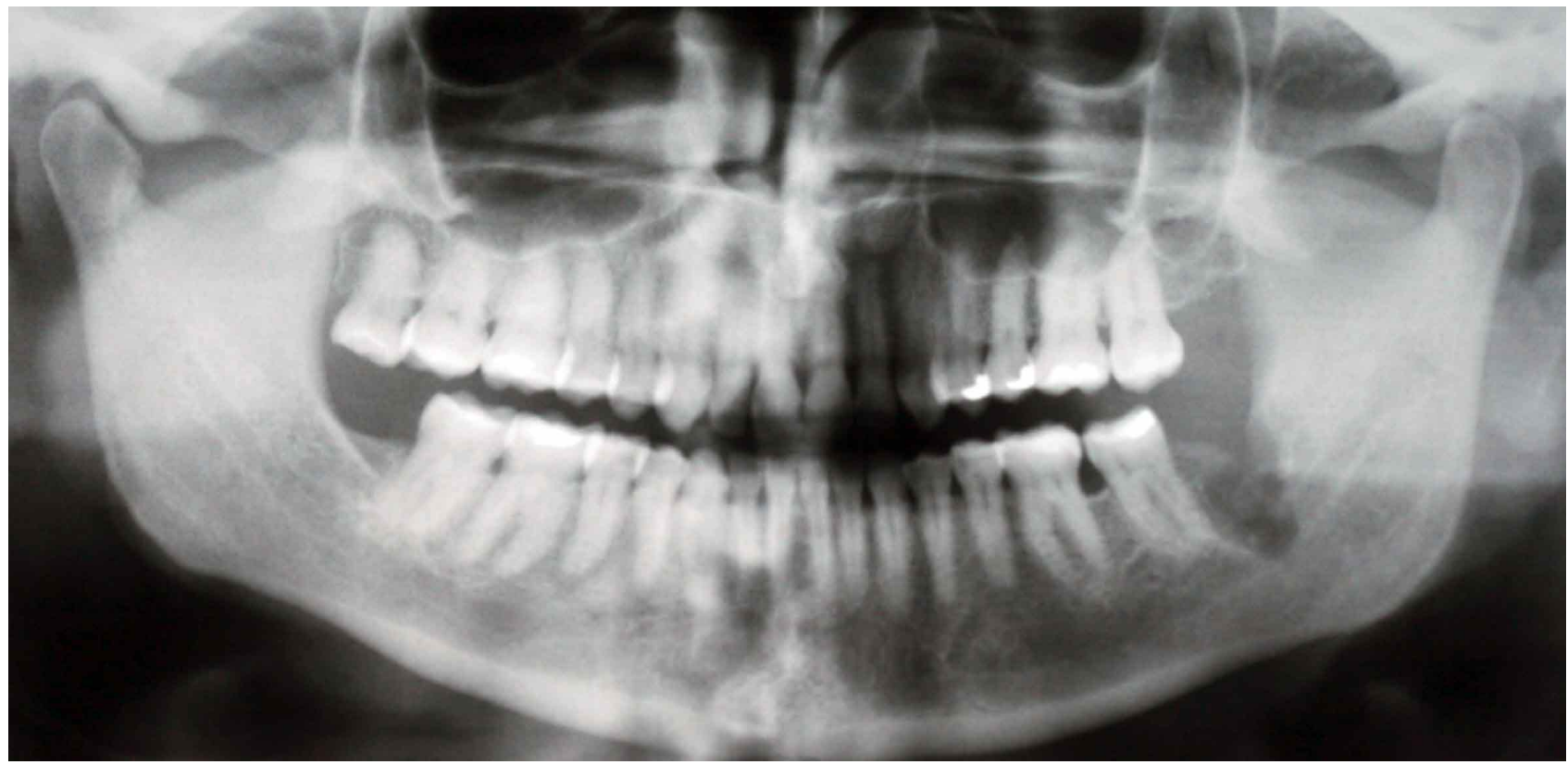

Fig. 5. Panoramic Radiographic, 85 days after angle fracture. 


\section{DISCUSSION}

Although surgical removal of impacted third molars is an operation that oral and maxillofacial surgeons perform frequently, mandibular fractures after third molar extractions are rare. In a retrospective study, Libersa et al., interviewed 150 oral and maxillofacial surgeons in northern France about their experiences with intraoperative and late mandibular fractures after third molar surgery. Among all the 750,000 extractions they had made, only 37 cases of fracture had been registered and subjected to clinical and radiograph examination (an incidence of $0.0049 \%$ ). Of those, however, only 27 had accurate descriptions; 17 of them had occurred in the intraoperative phase and 10 were late fractures. The authors found that: the highest incidence of immediate and late mandibular fractures was associated to patients aged 25 and over, men were more liable to have late fractures (8 cases out of 10 ). The mean age of intraoperative fracture patients was 37 and of late fracture patients, 47. Similarly, in 2000, Perry \& Goldberg investigated incidence and the etiological factors involved in late mandibular fractures after third molar surgery over a 10 -year period. A questionnaire was sent out to 106 surgeons in Connecticut asking them to register their experiences with this type of complication. $79 \%$ of the surgeons responded and indicated that only 28 fractures had been registered for a total of 611,000 extractions; an incidence of $0.0046 \%$. The factors involved were: age, gender, type of impactation, pre-existing infection, and failure to adhere to an appropriate diet in the postoperative period. Most fractures had occurred between the first and 21st days of the postoperative period. Based on those results, the authors concluded that men over 25 years old should be specifically informed about the risks of late mandibular fracture after third molar surgery and of the need to adhere to a light diet during the postoperative period (Ferre et al., 1981; Libersa et al.).

Some factors may be related to the occurrence of this kind of complication such as type of impaction, age, sex, presence of infection, bone lesions, the surgical technique employed and chewing solid foods after extraction (Libersa et al.; Al-Belasy et al., 2009). Impaction is a fundamental factor, because the greater the depth of impaction in relation to the neighboring second molar (Pell and Gregory Class B/C), the greater the amount of bony tissue that needs to be removed to get access to the tooth (Libersa et al.). In such cases, extensive osteotomy may weaken the mandible and make it more susceptible to fracturing (Krimmel \& Reinert, 2000), mainly because the angle of the jaw is an area of decreased resistance to fracture, due to its characteristic bony anatomy and its location between the branch and the body (Ferre et al.).

Age is another important risk factor for fracture, and Libersa et al., reported that $85 \%$ of patients presenting mandibular fractures after third molar extraction were over 25, with a mean age of 40 . Because the natural process of bone density increasing with age, in the older age group a greater amount of bone tissue will need to be removed, thereby weakening the mandible (Libersa et al.; Obiechina et al., 2001).

Regarding sex, there seems to have a particular importance in postoperative fractures, with the highest incidence for men, possibly due to greater masticatory force employed in male patients, emphasizing the need for soft diet during the first weeks post-surgery (Ferre et al.; Anil et al., 1998; Wagner et al., 2005). Late fractures generally occur during the act of chewing something and with a click audible to the patient, even like in this patient, however the same complication has been reported as a result of vigorous mouth rinsing (Custódio et al.; Assael; Perry \& Goldgerg; Woldenberg et al., 2007). The period of greatest risk appears to be actually the second and third weeks after surgery when granulation tissue is still being substituted by connecting tissue inside the alveolus. It seems that the end of the second week the patients are feeling better, the painful symptoms is already disappearing, and they believe they can chew normally. In the clinical case being reported here, some of these observations are applicable. The patient was a 50-year-old and about three weeks later, the removal of the left third molar, she chewed a piece of bread and her mandible fractured. In patients aged around 40 with a significant degree of impaction, the risk of fracture is heightened by the fragility of the bone resulting from the difficult nature of third molar removal procedure, which calls for a sizeable osteotomy. Records of the patient case showed that extensive osteotomy was performed. Most patients that suffered this complication reported hearing a sharp crack while they were chewing and simultaneously feeling a sharp pain. These patients would benefit from guidance on the possibility of mandibular fracture, and the benefit of dietary restriction to a liquid and soft diet for 45 days 
after extraction. Prophylactic extraction of third molars before age 20 could reduce the risks of such fractures (Libersa et al.; Al-Belasy et al.; Kao et al., 2010).

Reports of mandibular fractures subsequent to third molar extractions are rare, nevertheless, it is important to be aware of all the risk factors that favor such complications and addressing them enables the surgeon to individualize surgical procedures to ensure that they do not occur. When they do, however, the main goal of treatment must be to re-establish dental occlusion and full mandibular function, whether it be conservative or surgical treatment (Ellis \& Sinn; Woldenberg et al.).

ANDRADE, V. C.; NETO, P. J. O.; DE MORAES, M. \& ASPRINO, L. Fractura tardia de ángulo de mandibula post extracción de tercer molar impactado - reporte de un caso y revisión de factores predisponentes. Int. J. Odontostomat., 7(2):287292, 2013.

RESUMEN: Cirugía del tercer molar es el procedimiento quirúrgico más común en la cavidad oral. Cuando se indica la extracción, una cuidadosa planificación basada en los exámenes clínicos y radiográficos es esencial para evitar complicaciones postoperatorias como sangrado, alveolitis, infecciones, lesiones a los dientes adyacentes, comunicaciones oroantrales o incluso fracturas mandibulares. Aunque es raro, el riesgo de fracturas mandibulares postoperatorias después de la cirugía del tercer molar impactado se relaciona con algunos factores. Reportamos el caso de un paciente de 50 años de edad con queja de dolor en la región del ángulo mandibular izquierdo, quien y declaró que tres semanas antes se había extraído el tercer molar inferior izquierdo. Por tomografía computarizada se confirmó la presencia de una fractura en el ángulo mandibular. Este informe contribuye a mostrar los factores que predisponen para provocar esta lesión después de una revisión de la literatura, que muestran que el clínico los debería tener como consideración cuando indican la extracción de los terceros molares. Para evitar esta complicación, factores como el grado de impactación ósea, profundidad del diente en el hueso, proximidad al canal mandibular, posición en relación a dientes adyacentes, presencia de dilaceraciones radiculares, entre otras, deben ser tomadas en cuenta. Se presenta un caso de fractura mandibular tardía que ocurrió 21 días después de la extracción del tercer molar. Se realizó un tratamiento conservador y después de seis meses de seguimiento radiográfico y clínico, el paciente conservó completamente la función mandibular, con una oclusión normal y sin molestias.

PALABRAS CLAVE: tercer molar, extracción, fractura mandibular, complicación tardía.

\section{REFERENCES}

Al-Belasy, F. A.; Tozoglu, S. \& Ertas, U. Mastication and Late Mandibular Fracture After Surgery of Impacted Third Molars Associated With No Gross Pathology. J. Oral Maxillofac. Surg., 67(4):856-61, 2009.

Anil, P.; Punjabi, B. D. S. \& Thaller, S. R. Operative Techniques. In: Manson, P. N. Plastic and Reconstructive Surgery. New York, Springer-Verlag, 1998. pp.266-74.

Assael, L. A. Treatment of mandibular angle fractures. J. Oral Maxillofac. Surg., 52(7):757-61, 1994.

Custódio, A. L. N.; Júnior, D. C. M.; Cavalcanti, F. B. N.; Serpa, M. R.; Cosso, M. G. \& Faria, J. M. P. Considerations above the treatment of mandibular fracture after third molar removal. Arq. Bras. Odontol., 3(2):106-13, 2007.

Ellis, E. 3rd. \& Sinn, D. P. Treatment of the mandibular angle fractures using $2.4 \mathrm{~mm}$ dynamic compression plates. J. Oral Maxillofac. Surg., 51(9):969-73, 1993.

Ferre, J. C.; Helary, J. L.; Lumineau, J. P. \& Legoux, R. Study of mandibular mechanics employing current methods for assessing resistance of materials. Recent concepts relative to mandibular mechanical structure. Rev. Stomatol. Chir. Maxillofac., 82(4):258-64, 1981.

Kao, Y. H.; Huang, I. E.; Chen, C. M.; Wu, C. W.; Hsu, K. J. \& Chen, C. M. Late mandibular fracture after lower third molar extraction in a patient with Stafne bone cavity: a case report. J. Oral Maxillofac. Surg., 68(7):1698-700, 2010.

Krimmel, M. \& Reinert, S. Mandibular fracture after third molar removal. J. Oral Maxillofacial. Surg., 58(10):11102, 2000 .

Kruger, E. Mandibular fractures. In: Kruger, E. \& Schilli, W. (Eds.). Oral Maxillofacial Traumatology. Chicago, Quintessence, 1982. pp.211-36.

Libersa, P.; Roze, D.; Cachart, T. \& Libersa, J. C. Immediate and late mandibular fractures after third molar removal. J. Oral Maxillofac. Surg., 60(2):163-6, 2002. 
Obiechina, A. E.; Oji, C. \& Fasola, A. O. Impacted mandibular third molars: Depth of impaction and surgical methods of extraction among Nigerians. Odontostomatol. Trop., 24(94):33-6, 2001.

Perry, P. A. \& Goldgerg, M. H. Late mandibular fracture after third molar surgery: A survey of Connecticut oral and maxillofacial surgeons. J. Oral Maxillofac. Surg., 58(8):858-61, 2000.

Wagner, K. W.; Otten, J. E.; Schoen, R. \& Schmelzeisen, R. Pathological mandibular fractures following third molar removal. Int. J. Oral Maxillofac. Surg., 34(7):722-6, 2005.

Woldenberg, Y.; Gatot, I. \& Bodner, L. Iatrogenic mandibular fracture associated with third molar removal. Can it be prevented? Med. Oral Patol. Cir. Bucal, 12(1):E70-2, 2007.
Correspondence to:

Valdir Cabral Andrade

Department of Oral Diagnosis

Oral and Maxillofacial Surgery Division

State University of Campinas-UNICAMP

Piracicaba Dental School

Avenida Limeira 901, CP 52

Bairro Vila Areão

CEP: 13.414-903

Piracicaba, São Paulo State

BRAZIL

Email: valdir_cv@yahoo.com.br

Received: 05-11-2012

Accepted: 02-04-2013 